\title{
$\mathrm{DC}$ 전해 커패시터의 고장진단 기준모델 입력을 위한 외부변수의 특성 고찰
}

\section{Characteristic Investigation of External Parameters for Fault Diagnosis Reference Model Input of DC Electrolytic Capacitor}

\author{
박 종 찬*손 진 근 \\ (Jong-Chan Park $\cdot$ Jin-Geun Shon)
}

\begin{abstract}
DC Bus Electrolytic capacitors have been widely used in power conversion system because they can achieve high capacitance and voltage ratings with volumetric efficiency and low cost. This type of capacitors have been traditionally used for filtering, voltage smoothing, by-pass and other many applications in power conversion circuits requiring a cost effective and volumetric efficiency components. Unfortunately, electrolytic capacitors are some of the weakest components in power electronic converter. Many papers have proposed different methods or algorithms to determinate the ESR and/or capacitance $\mathrm{C}$ for fault diagnosis of the electrolytic capacitor. However, both ESR and C vary with frequency and temperature. Accurate knowledge of both values at the capacitors operating conditions is essential to achieve the best reference data of fault judgement. According to parameter analysis, the capacitance increases with temperature and the ESR decreases. Higher frequencies make the ESR and C to decrease. Analysis results show that the proposed electrolytic capacitor parameter estimation technique can be applied to reference signal of capacitor diagnosis systems successfully.
\end{abstract}

Key Words : DC electrolytic capacitor, Equivalent Series Resistance(ESR), Power electronic converter, Reference data, Capacitor diagnosis.

\section{1. 서 론}

$\mathrm{AC} / \mathrm{DC}$ 컨버터 및 $\mathrm{DC} / \mathrm{AC}$ 인버터 등의 기본적인 전력변 환장치뿐 만 아니라 최근의 전기자동차용 충전장치나 태양 광이나 풍력발전 등 신재생에너지의 전력변환 분야에 사용 되는 $\mathrm{DC} / \mathrm{DC}$ 컨버터부에는 거의 대부분 전압의 연계(link) 및 DC 평활화(smoothing)를 위하여 알루미늄 전해 커패시 터를 사용하고 있다. 이는 다른 커패시터에 비하여 용량이 상대적으로 크고 높은 내전압을 가지면서도 비교적 가격이 저렴하다는 장점 때문에 많이 사용되고 있다. 그러나 이러 한 커패시터는 사용시간의 증대에 따라 서서히 열화가 진행 되면서 전해질의 온도 및 유전 특성이 나빠지면서 고장의 주요인이 된다.

1995년 미국 국방전자장비보고서[1]에 의하면 전력용 반 도체 스위치를 이용한 전력변환장치의 주요 구성 부품 중에 서 사고인자의 60[\%]가 반도체 소자가 아닌 전해 커패시터 가 차지하고 있음을 경각시켜주고 있다. 이러한 알루미늄 $\mathrm{DC}$ 전해 커패시터는 고온에서 성능이 급격하게 감소되어 전해액의 증발 및 전류 맥동(ripple) 과다에 의하여 부품의

\footnotetext{
* 연구책임자, 시니어회원 : 오산대학교 전기시스템제어과 교수 · 공박.

† 교신저자, 정회원 : 가천대학교, 전기공학과 교수, 공박. E-mail:shon@gachon.ac.kr

접수일자 : 2012년 10월 9일

최종완료 : 2012년 11월 13일
}

파손에 의한 전력변환시스템의 고장 및 전원계통 사고의 위 험 요인으로 작용하게 된다. 따라서 이러한 부품사고의 예 방진단 및 부품의 최적 교체를 위하여 오프라인 및 온라인 방식의 다양한 진단 알고리즘이 최근 활발히 연구되고 있 다. 이러한 진단 알고리즘의 대부분은 커패시터 내부 파라 미터를 이용하게 되는데, 거의 대부분은 커패시터 등가직렬 저항 $\mathrm{ESR}$ 값이나 커패시턴스 용량 $\mathrm{C}$ 값을 추정하는 방식이 주종을 이루며 아주 가끔씩은 커패시터의 유전체손실 $(\tan \delta)$ 의 파라미터를 추정하는 방식도 보고되고 있다[2,3].

이러한 DC 전해 커패시터에 대한 고장진단 알고리즘은 파라미터의 초기 기준 값을 선정하여 입력하게 되는데, $\mathrm{ESR}$ 값은 초기 선정 값의 약 2 배 증가 시에 그리고 커패시 턴스 C값의 용량이 초기 값 보다 약 25[\%] 감소 시에 수명 말기로 판단하여 진단하고 있다[4]. 그러나 전해 커패시터 고장진단의 기준모델 파라미터는 사용 온도와 운전 주파수 의 조건에 따라 그 값이 현격히 변화하게 된다. 실제 전력 변환장치 내부에 존재하는 전해 커패시터는 부하의 가변 및 운전 조건에 따라 온도 및 운전 주파수의 사용 조건이 끊임 없이 변화하기 때문에 전해 커패시터 고장 판별의 기준이 되는 파리미터의 기준모델 값 역시 이에 대한 영향을 반영 해야 정확한 고장 진단 기법을 구현할 수 있다.

따라서 본 논문에서는 온도 및 주파수 변화에 따른 $\mathrm{ESR}$ 과 커패시턴스 $\mathrm{C}$ 값의 특성 변화에 대한 상관관계를 다양한 조건과 관점에서 그 특성을 고찰하고자 한다. 이의 결과를 이용하여 본 저자들이 기존에 시스템을 구축하여 발표한 바 있는 $\mathrm{ESR}$ 과 $\mathrm{C}$ 에 의한 고장진단 시스템 $[5,6]$ 에 추가로 반영 
하도록 하여 보다 정확하고 신뢰성 있는 고장 진단시스템이 되도록 기능을 추가시키는 계획으로 삼고자 한다.

\section{2. 전해 커패시터의 특성과 고장판별의 기준모델}

$\mathrm{DC}$ 전압의 평활화를 위해 사용되는 알루미늄 전해 커패 시터의 임피던스 특성은 온도 및 주파수 가변에 따라 그 크 기가 변화하게 된다. 온도의 가변에 따라서 임피던스의 크 기가 변하게 되며 또한 커패시터의 화학반응 속도상수가 아 레니우스 방정식[4]에 따라 변한다고 보고되고 있다. 그리고 주파수 가변에 따라 커패시터의 임피던스 특성은 저주파 영 역에서는 커패시터의 성분이 지배적이며, 스위칭 주파수 영 역에서는 저항성분의 특성이 나타나 $\mathrm{ESR}$ 성분을 추출할 수 있으며, 고주파 영역에서는 인덕터 성분이 지배적이며, 이에 대한 결과현상을 그림 1 에서 확인할 수 있다.

즉, 전해 커패시터의 구조는 RLC 직렬등가회로로 간략화 시킬 수 있으며 이의 임피던스 특성은 주파수 변화에 따라 그림 1 과 같이 다르게 나타난다. 그림 1 은 등가직렬저항 및 직렬인덕터 즉, $\mathrm{ESR}$ 및 $\mathrm{ESL}$ 값이 각각 $1[\Omega], 100[\mu H]$ 로 선 정하고 커패시턴스 값은 $470[\mu F]$ 로 선정하여 Saber 프로그 램을 이용하여 주파수 변화에 따른 임피던스의 변화 특성을 시뮬레이션을 수행한 결과이다. 주파수 가변에 따른 위상변 화(deg.)의 결과 및 임피던스의 크기 $(\mathrm{Ohm})$ 에 대한 결과는 이의 그림 1 에서 알 수 있듯이 저주파 영역(section 1)에서 는 커패시터의 성분이 지배적(dominant)이며, 수[kHz] 또는 수 십 $[\mathrm{kHz}]$ 등의 스위칭 주파수 영역(section 2)에서는 저 항성분인 $\mathrm{ESR}$ 이 지배적이며, 고주파 영역(section 3)에서는 $\mathrm{ESL}$ 값이 지배적임을 알 수 있다.

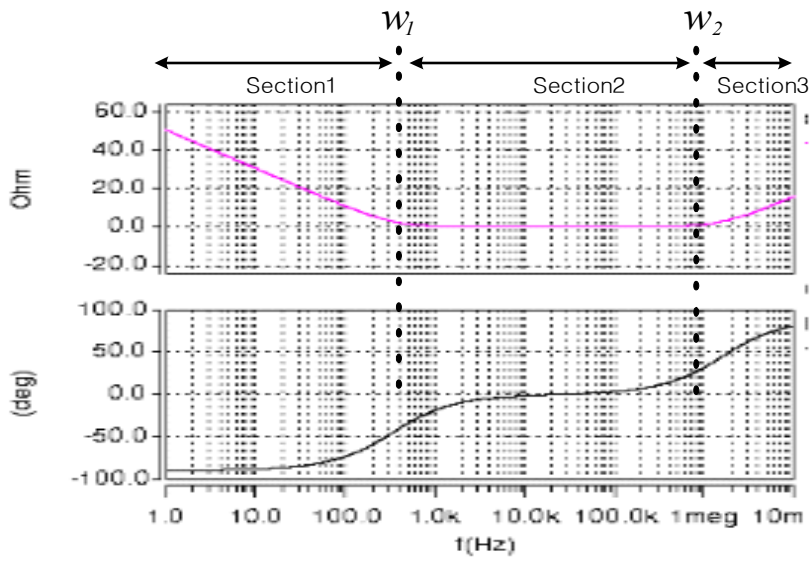

그림 1 전해 커패시터의 가변 주파수에 따른 임피던스 특성

Fig. 1 Impedance characteristics with the variable frequency of electrolytic capacitor.

한편, 알루미늄 $\mathrm{DC}$ 전해 커패시터는 사용시간의 증가에 따라 열화가 진행되어 온도 상승 및 전해액의 분출 사고를 유발하게 된다. 이러한 커패시터의 고장 대부분은 전기화학 적 반응에 의하여 나타나게 되는데 이는 전해액의 감소 및 전해액 증기분출, 양극과 음극에서의 커패시턴스 감소로 나 타나게 되며 이의 요인으로는 온도 및 사용전압 그리고 맥 동전류 등의 초과에 의해서 발생된다. 특히 온도의 초과는 전해액 성능과 직접 관련이 있으며 기타 맥동 전류의 증가
에 의하여 온도 상승을 가중시키게 된다.

따라서 전해 커패시터의 고장 및 열화의 메커니즘은 온도 상승에 따른 전해액의 증발(dry-up)이 가장 큰 요인이며, 이 에 따라 $\mathrm{ESR}$ 의 증가 및 정전용량의 감소, 유전율 $\tan \delta$ 의 증가를 초래한다고 할 수 있다. 이때의 커패시터에 대한 고 장 판별의 기준은 제조사별로 약간은 다르겠지만 대부분은 표 1 의 기준으로 커패시터를 판별한다고 보고되고 있다. 이는 커패시턴스의 정전용량 감소는 정격 $\mathrm{DC} 160[\mathrm{~V}]$ 이하에 서는 약 $15[\%], \quad \mathrm{DC} 160[\mathrm{~V}]$ 이상에서는 10[\%]감소를 고장 징후의 시작으로 보고, 약 25[\%]이상으로 이어질 경우에는 이를 수명 말기로 판단하여 고장에 대비하게 된다. 또한 $\mathrm{ESR}$ 의 상승에 대해서는 이의 값이 초기 값 대비 약 2 배 이 상일 경우 그리고 $\tan \delta$ 는 초기 값 대비 약 1.3 배 이상일 경 우에 이상(abnormal) 징후의 시작으로 판단하여 고장진단 알고리즘에 적용하는 것이 일반적이다[4,5].

표 $\quad 1$ 커패시터 고장판별의 기준

Table 1 The failure standard of electrolytic capacitor.

- $\Delta \mathrm{C}=$ 정격전압 $\mathrm{Vr} \leq 160\left[\mathrm{~V}_{\mathrm{DC}}\right]$ 일 때 $15[\%]$ 감소 시 정격전압 $\mathrm{Vr}>160\left[\mathrm{~V}_{\mathrm{DC}}\right]$ 일 때는 $10[\%]$ 감소 시

- ESR이 초기치 보다 2배 클 때

- $\mathrm{DF}(\tan \delta)$ 가 정격보다 1.3 배 클 때

이와 같이 $\mathrm{DC}$ 전해 커패시터에 대한 고장진단 알고리즘 은 그림 2 의 절차와 같이 파라미터의 초기 기준 값을 선정 하여 입력하게 된다. 그러나 전해 커패시터 고장진단의 기준 모델 파라미터는 사용 온도와 운전 주파수 조건에 따라 그 값이 현격히 변화하게 되기 때문에 전해 커패시터 고장 판 별의 기준이 되는 파리미터의 기준모델 값 역시 이에 대한 영향을 반영해야 정확한 고장 진단 기법을 구현할 수 있다.

따라서 본 논문에서는 온도 및 주파수 변화에 따른 $\mathrm{ESR}$ 과 커패시턴스 $\mathrm{C}$ 값의 특성 변화에 대한 상관관계를 다양한 조건에서 그 특성을 고찰하여 추후 보다 더 정확하고 신뢰 성 있는 고장 진단시스템이 구축되도록 본 연구결과를 활용 할 계획이다.

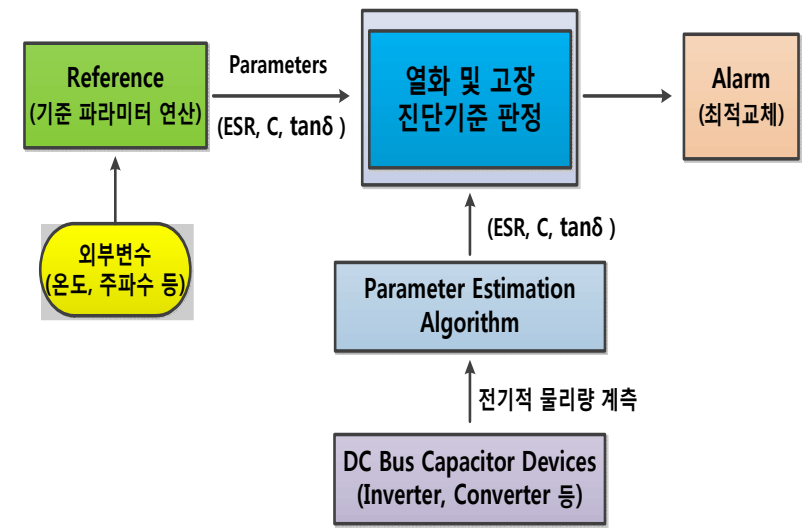

그림 2 외부변수를 고려한 커패시터 고장진단의 기준모델

Fig. 2 Reference model of capacitor diagnosis considering external parameters. 


\section{3. 온도 및 주파수 가변의 전해 커패시터 모델링[6]}

$\mathrm{PWM}$ 컨버터와 같은 전력변환 장치에서의 $\mathrm{DC}$ 링크 전해 커패시터는 전압의 평활화 및 에너지의 일시적 저장을 위하 여 많이 사용된다. 이러한 커패시터의 등가회로는 간략히 $\mathrm{RLC}$ 직렬로 표현된다. 커패시턴스 $\mathrm{C}$ 의 생성은 Anode와 Cathode의 양쪽 극에서 발생된다. 이때 등가직렬저항 ESR 은 알루미늄 호일과 터미널에 의한 고정 값의 $R_{1}$ 이 있고, 전해질에 의해서 발생되고 온도에 영향을 받는 $R_{2}$ 가 존재하 며, 유전체 누설저항에 의해서 발생되고 주파수에 영향을 받 는 $R_{3}$ 로 구성된다. 마찬가지로 커패시턴스 $\mathrm{C}$ 는 $\mathrm{ESR}$ 의 $R_{1}$, $R_{2}, R_{3}$ 의 구성과 같이 고정값 $C_{1}$, 온도 및 주파수에 영향 을 받는 $C_{2}, C_{3}$ 로 구분하여 구성할 수 있다. 따라서 전체의 $\mathrm{ESR}$ 및 C값은 식 (1), (2)와 같은 함수로 표현 할 수 있다 [7].

$$
\begin{aligned}
& E S R=R_{1}+R_{2}(T)+R_{3}(f) \\
& C=C_{1}+C_{2}(T)+C_{3}(f)
\end{aligned}
$$

여기서, $R_{1}$ 은 호일과 연결 탭 및 터미널의 기계적 접촉 저항이므로 상수로 근사화 할 수 있으며, 일반적으로 약 10 $[m \Omega]$ 정도의 값을 갖고 $C_{1}$ 역시 일정 상수로 근사화 할 수 있다.

$$
\begin{aligned}
& R_{1} \cong \text { constant } \\
& C_{1} \cong \text { constant }
\end{aligned}
$$

또한 $R_{2}$ 와 $C_{2}$ 는 온도의 영향을 받는 파라미터로 식 (5)와 식 (6)으로 상세 표현할 수 있다. 즉, $R_{2}$ 은 전해질에 의해서 발생되고 온도의 영향을 받는 저항이며, 온도가 증가할수록 감소하는 부 온도계수의 특징이 있다. 온도가 $25\left[{ }^{\circ} \mathrm{C}\right]$ 이상인 경우에는 화학반응의 속도 상수는 온도와 활성화 에너지에 의존한다는 아레니우스 방정식에 기초한 방정식으로 표현할 수 있다. 반면 $25\left[{ }^{\circ} \mathrm{C}\right]$ 이하인 경우에는 이러한 접근 방법이 많은 오차를 동반하므로 별도의 해석이 필요하다.

이때, $25\left[{ }^{\circ} \mathrm{C}\right]$ 이상의 온도 영역에서 전해액과 전해지의 결 합에 의해서 온도에 의존하는 $R_{2}$ 의 해석은 실온일 때의 저 항 $R_{2}\left(25^{\circ} \mathrm{C}\right)$ 에 기초하여 식 (5)와 같이 표현할 수 있다. 여 기서 $\mathrm{A}$ 와 $\mathrm{B}$ 는 전해액과 절연지에 관계되는 계수로써, 에틸 렌글리콜(ethylene glycol)이 전해액인 경우 $\mathrm{A}=40$ 그리고 $\mathrm{B}=0.6$ 으로 선정된다.

$$
R_{2}(T)=R_{2}\left(25^{\circ} \mathrm{C}\right) \cdot 2^{-\left[\frac{T-25}{A}\right]^{B}}
$$

또한 $C_{2}$ 는 온도상승 계수에 비례하여 증가한다는 특징 식으로 식 (6)과 같이 표현된다. 여기서, $\mathrm{A}$ 와 $\mathrm{B}$ 는 전해액과 절연지에 관계되는 계수이며, $\lambda$ 는 온도상승 계수이다.

$$
C_{2}(T)=\lambda \cdot T
$$

또한 $R_{3}$ 와 $C_{3}$ 는 주파수의 영향을 받는 파라미터이며, 주 파수가 증가하면 $R_{3}$ 와 $C_{3}$ 는 감소하게 되며 이를 식 (7)과 식 (8)로 표현할 수 있다. 여기서 $D_{o x}$ 는 유전체에 의한 발열 손실계수(Dissipation Factor, $\tan \delta$ ), $f$ 는 주파수, $C$ 는 전해 커패시터의 커패시턴스이다. $\mathrm{ESR}$ 의 구성 비율 중 주파수의 영향을 받는 $R_{3}$ 의 비중은 정격전압이 높을수록 커지는데, 이는 전해 커패시터의 정격 전압이 높을수록 산화막이 두꺼 워지기 때문이다. 전형적인 발열손실계수(D.F.) 값은 $D_{o x}=$ $0.06 \sim 0.1$ 이며, 일반적으로 0.075 정도이다[7].

$$
\begin{aligned}
& R_{3}(f)=\frac{D_{o x}}{2 \pi f C} \\
& C_{3}(f)=\frac{1}{2 \pi f Z}
\end{aligned}
$$

\section{4. 주파수 및 온도 가변에 따른 $\mathrm{ESR}$ 의 특성 고찰}

$\mathrm{DC}$ 전해 커패시터의 고장진단 기준모델 입력을 위한 파 라미터의 특성고찰을 위하여 본 논문에서의 사용된 커패시 터 파라미터 사양과 설정 계수를 표 2에 나타내었다.

표 2 커패시터의 사양과 파라미터 선정

Table 2 The specification and parameters of capacitor.

\begin{tabular}{c|c}
\hline \hline 파라미터 항목 & 파라미터 값 \\
\hline 정격 전압 & $400[\mathrm{~V}]$ \\
\hline 최대 동작 온도 & $105\left[{ }^{\circ} \mathrm{C}\right]$ \\
\hline 커패시터 용량 & $470[\mu F]$ \\
\hline$R_{1}, R_{2}\left(25^{\circ} \mathrm{C}\right)$ & $0.035[\Omega], 0.12[\Omega]$ \\
\hline 전해액 계수(A) & 40 \\
\hline 절연지 계수(B) $(\mathrm{B})$ & 0.6 \\
\hline 발연 손실 계수 $\left(D_{o x}\right)$ & 0.075 \\
\hline 온도 상승 계수 $[\lambda]$ & 2.5 \\
\hline 샘플링 시간 & $100[\mu s]$ \\
\hline \hline
\end{tabular}

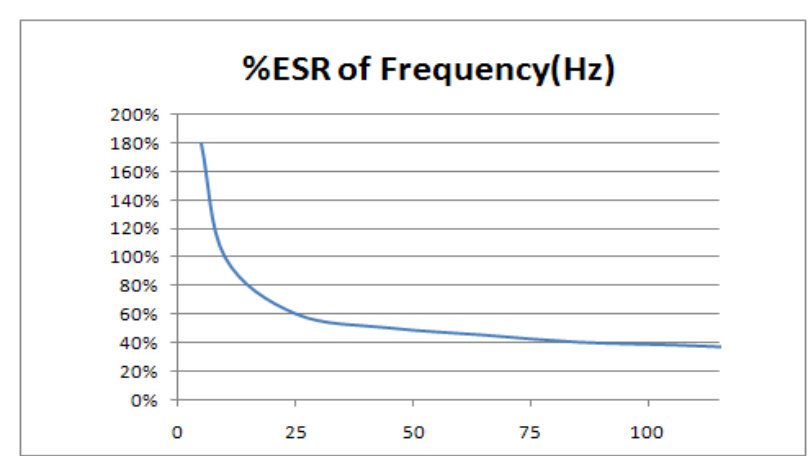

그림 3 저주파 영역 $(f \leq 120[\mathrm{~Hz}])$ 에서의 기준 $\mathrm{ESR}$ 변화

Fig. 3 ESR results with the low frequency variation. $\left(\mathrm{T}=25^{\circ} \mathrm{C}, f \leq 120[\mathrm{~Hz}]\right)$

그림 3 과 그림 4 는 일정 온도 $\left(\mathrm{T}=25\left[{ }^{\circ} \mathrm{C}\right]\right)$ 조건에서 주파수 가변에 따른 기준 $\mathrm{ESR}$ 변화를 저주파 영역 및 고주파 영역 에서 각각 나타낸 그래프이다. 일정 온도의 조건에서 주파 
수 가변에 따른 기준 $\mathrm{ESR}$ 변화는 온도 조건에 상관없이 주 파수 약 25[Hz] 이하에서는 ESR값이 매우 크게 나타났으며, $1[\mathrm{kHz}]$ 이상의 비교적 고주파 영역에서는 거의 변화가 없으 므로, 스위칭 영역인 수 $[\mathrm{kHz}]$ 영역에서의 주파수 변화에 대한 $\mathrm{ESR}$ 의 영향은 무시할 수 있다고 판단할 수 있으며 저 주파 영역에서는 이의 특성을 고려해야 한다고 판단된다.

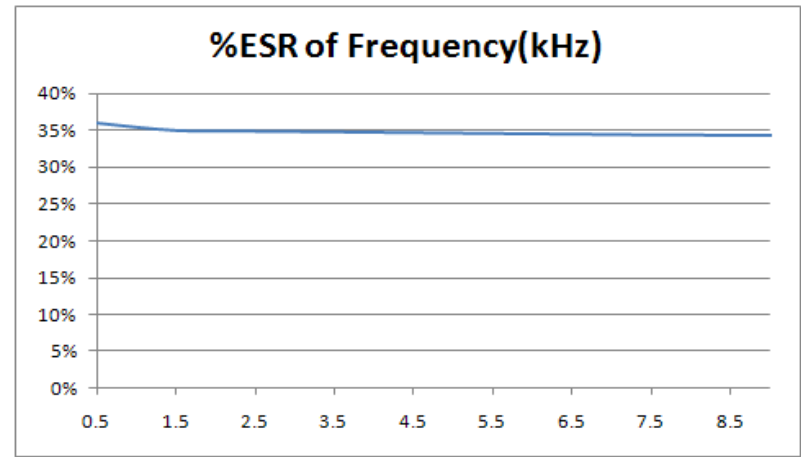

그림 4 고주파 영역 $(f \geq 0.5[\mathrm{kHz}])$ 에서의 기준 $\mathrm{ESR}$ 변화

Fig. 4 ESR results with the high frequency variation.

$\left(\mathrm{T}=25^{\circ} \mathrm{C}, f \geq 0.5[\mathrm{kHz}]\right)$

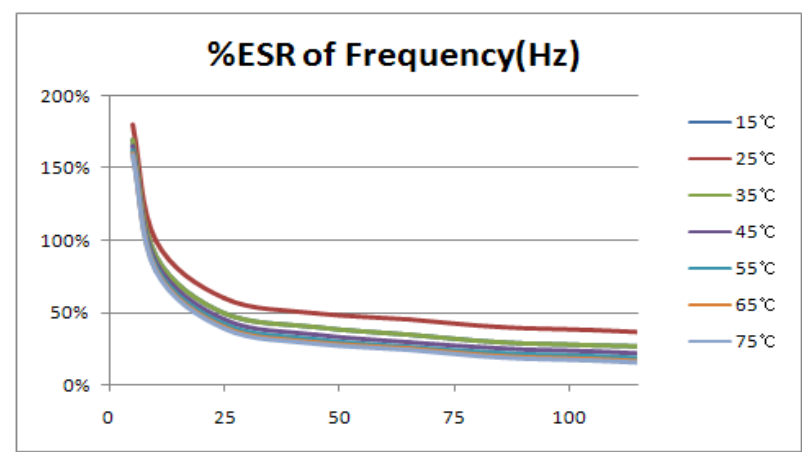

그림 5 온도 및 저주파수 가변에 따른 기준 ESR 변화

Fig. 5 ESR results with the temperature and frequency variation( $f \leq 120[\mathrm{~Hz}])$.

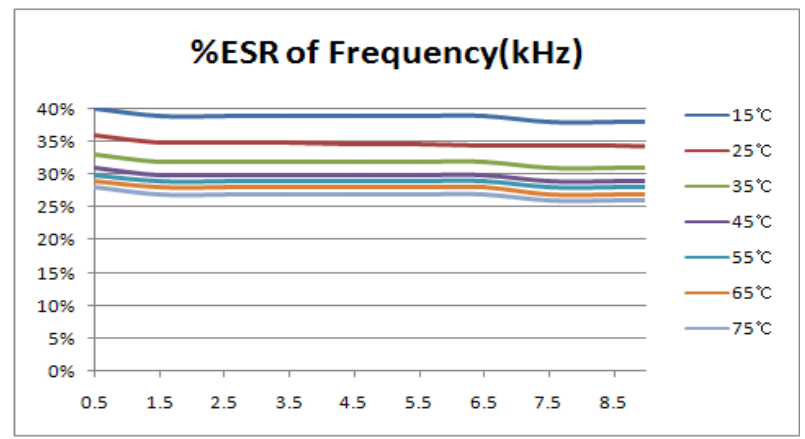

그림 6 온도 및 고주파수 가변에 따른 기준 ESR 변화

Fig. 6 ESR results with the temperature and frequency variation $(f \geq 0.5[k H z])$.

그림 5는 $15 \sim 75\left[{ }^{\circ} \mathrm{C}\right]$ 까지 다양한 온도 조건에서의 주파수 가변 $(\mathrm{f}<120[\mathrm{~Hz}])$ 에 따른 기준 $\mathrm{ESR}$ 변화이다. 온도 조건에
상관없이 주파수 $25[\mathrm{~Hz}]$ 이하에서는 $\mathrm{ESR}$ 값이 매우 큰 과도 의 특성을 확인 할 수 있다. 또한 그림 6 은 그림 5 와 같은 다양한 온도 조건에서의 주파수 가변 $(\mathrm{f}>0.5[\mathrm{kHz}])$ 에 따른 기 준 $\mathrm{ESR}$ 변화이다. 주파수 증가에 따라서 $\mathrm{ESR}$ 은 미소하게 감소하지만 큰 영향은 없으며 다만 $1[\mathrm{kHz}]$ 이상에서의 가변 온도 조건에서는 $\mathrm{ESR}$ 의 초기치 부터 크기 값이 정해져서 변동됨을 알 수 있다.

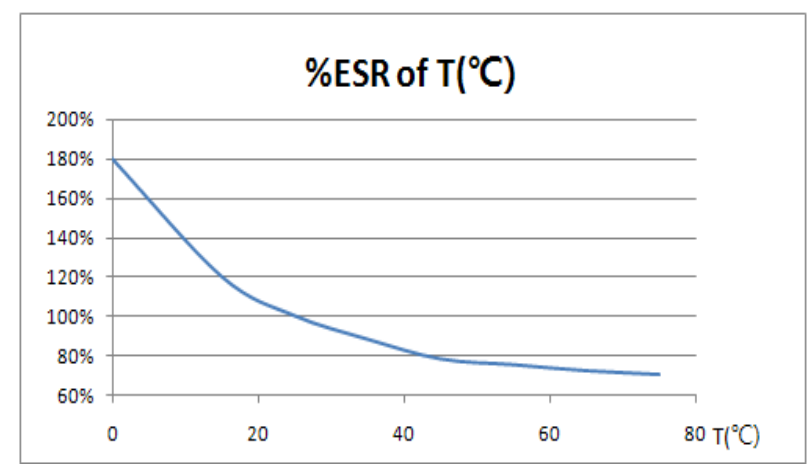

그림 7 온도 가변에 따른 ESR 변화

Fig. $7 \mathrm{ESR}$ results with the temperature variation. $\left(0<{ }^{\circ} \mathrm{C}<75\right)$

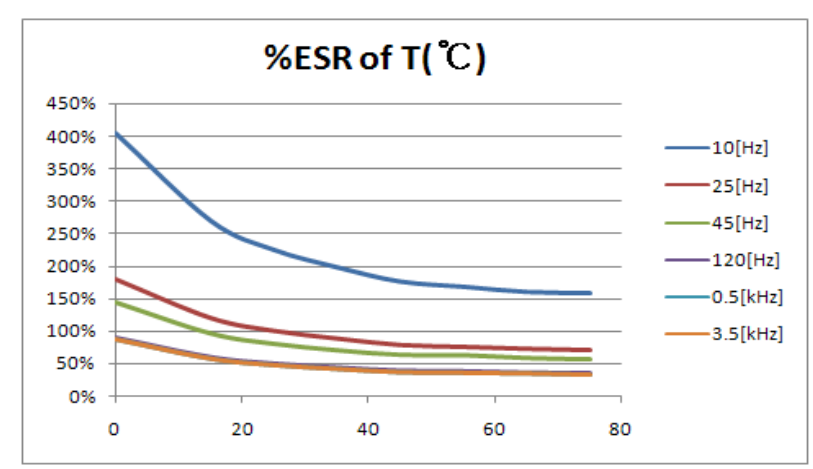

그림 8 다양한 주파수에서 온도 가변에 따른 ESR 변화

Fig. 8 ESR results with the temperature and frequency variation. $\left(0<{ }^{\circ} \mathrm{C}<75\right)$

그림 7은 넓은 범위의 온도가변에 따른 $\mathrm{ESR}$ 의 특성을 나 타낸 그림이다. 또한 그림 8은 다양한 주파수에서의 온도가 변에 따른 기준 $\mathrm{ESR}$ 변화를 나타낸 것으로 주파수 조건에 크게 상관없이 주로 온도 특성에 의하여 거의 같은 패턴으 로 $\mathrm{ESR}$ 이 변하는 것을 확인 할 수 있다. 또한 그림 7에서 처럼 온도가 증가함에 따라서 전해질의 전도율이 증가 하는 것은 $\mathrm{ESR}$ 이 감소하는 원인이 된다. 높은 정격 전압의 전해 커패시터는 낮은 정격 전압의 전해커패시터 보다 온도에 민 감해 진다. 그 이유는 높은 전압의 전해커패시터 일수록 더 낮은 전도율의 전해질을 사용하기 때문이다[3]. 식 (5)의 표 현처럼 어떤 실내 온도에서의 $25\left[{ }^{\circ} \mathrm{C}\right]$ 에서의 $\mathrm{ESR}$ 저항 $\left(R_{2}\right)$ 를 이용하여 표준화된 전해질 저항의 온도 민감도를 도출해 낼 수 있다. 온도가 증가함에 따라서 등가직렬저항이 온도 값 의 반으로 떨어지는 것과 같은 결과가 될 수 있음을 쉽게 알 수 있다. 
제조사는 자사 제품에 대한 등가직렬저항 $\mathrm{ESR}$ 의 온도효 과를 보여주는 특성곡선을 제공해 주는 경우도 있다. 이러 한 곡선은 리플전류의 곱셈의 형태로 세워진 모델에서 구성 요소에 대한 특성 값을 유추하는데 사용된다. 그러나 제조 사의 특성곡선을 이용하는 것 보다 더 정교한 대안은 등가 직렬저항과 커패시턴스를 다양한 온도범위와 주파수 범위에 서 실험적으로 측정하는 것이라고 할 수 있다.

\section{5. 주파수 및 온도 가변에 따른 $\mathrm{C}$ 값의 특성 고찰}

앞장에서의 ESR과 마찬가지로 커패시턴스 용량 추정기법 역시 커패시터의 진단 파라미터로 매우 중요하며 이의 판단 기준은 표 2에서 설명한바와 같으며 임피던스의 특성 및 용 량은 주파수에 영향을 받게 된다.

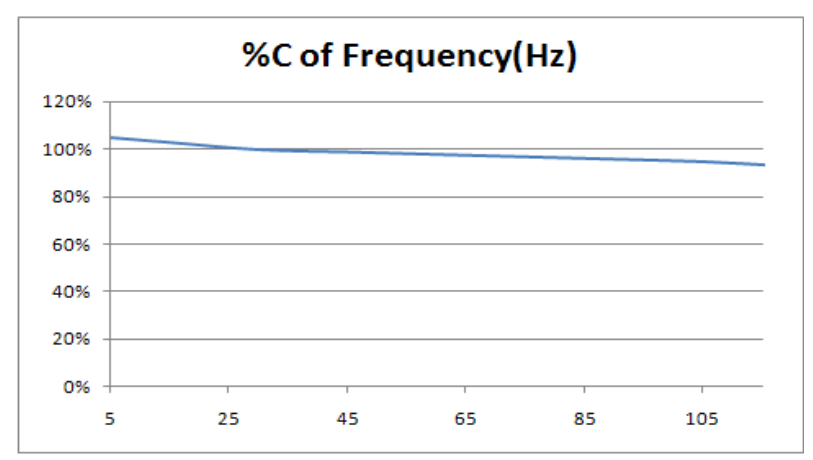

그림 9 저주파 영역 $(f \leq 120[\mathrm{~Hz}])$ 에서의 기준 C값 변화

Fig. 9 Capacitance results with the low frequency variation. $\left(\mathrm{T}=25^{\circ} \mathrm{C}, f \leq 120[\mathrm{~Hz}]\right)$

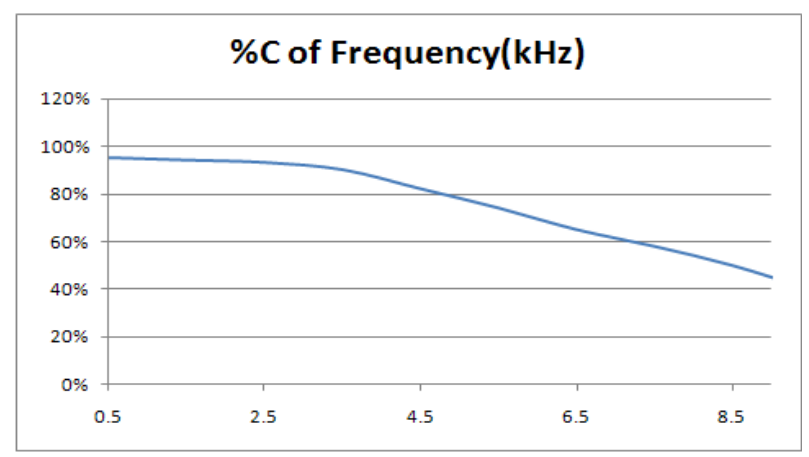

그림 10 고주파 영역에서의 기준 C값 변화

Fig. 10 Capacitance results with the high frequency variation. $\left(\mathrm{T}=25^{\circ} \mathrm{C}, f \geq 0.5[\mathrm{kHz}]\right)$

그림 9와 그림 10은 저주파수 및 고주파수의 변화에 따른 $\mathrm{C}$ 값의 특성 변화를 나타낸다. 그림 9 에서 알 수 있듯이 저 주파 영역에서의 커패시터의 용량은 큰 변화가 없지만 그림 10 과 같이 고주파 영역에서의 커패시터 용량은 큰 변화를 보인다.

그림 11 은 다양한 온도 조건에서의 낮은 주파수의 가변 $(\mathrm{f}<120[\mathrm{~Hz}])$ 에 따른 기준 $\mathrm{C}$ 값의 변화이다. 온도 조건에 상 관없이 $120[\mathrm{~Hz}]$ 이하의 저주파 영역에서는 같은 패턴으로 $\mathrm{C}$ 값 변화가 미미하여 여전히 무시할 수 있다. 그림 12 는 다
양한 온도 조건에서의 높은 주파수 가변 $(\mathrm{f}>0.5[\mathrm{kHz}])$ 에 따른 기준 $\mathrm{C}$ 값의 변화이다. 주파수 증가에 따라서 $\mathrm{C}$ 값은 크게 감 소하지만 가변 온도 조건에는 동일한 패턴으로 크게 다르지 않게 변화되고 있음을 확인할 수 있다.

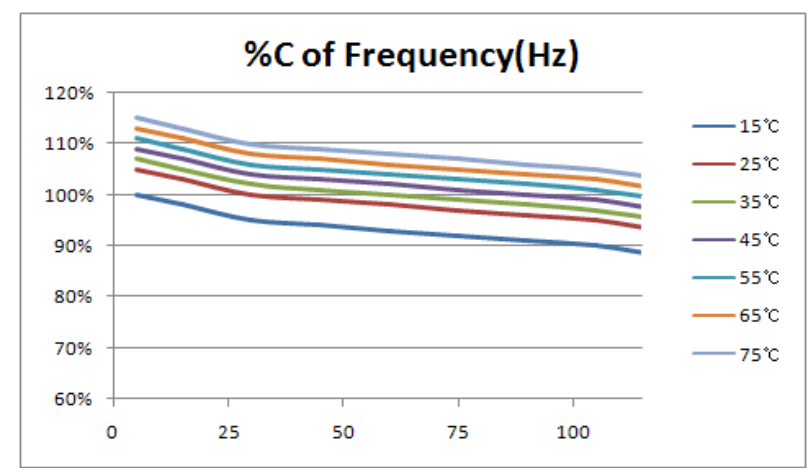

그림 11 온도 및 저주파수 가변에 따른 기준 $\mathrm{C}$ 값 변화

Fig. 11 Capacitance results with the temperature and frequency variation $(f \leq 120[\mathrm{~Hz}])$.

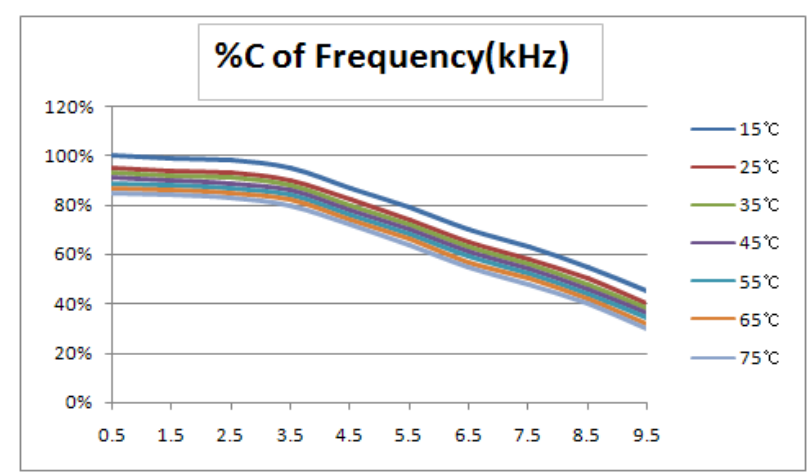

그림 12 온도 및 고주파수 가변에 따른 기준 C값 변화

Fig. 12 Capacitance results with the temperature and frequency variation $(f \geq 0.5[\mathrm{kHz}])$.

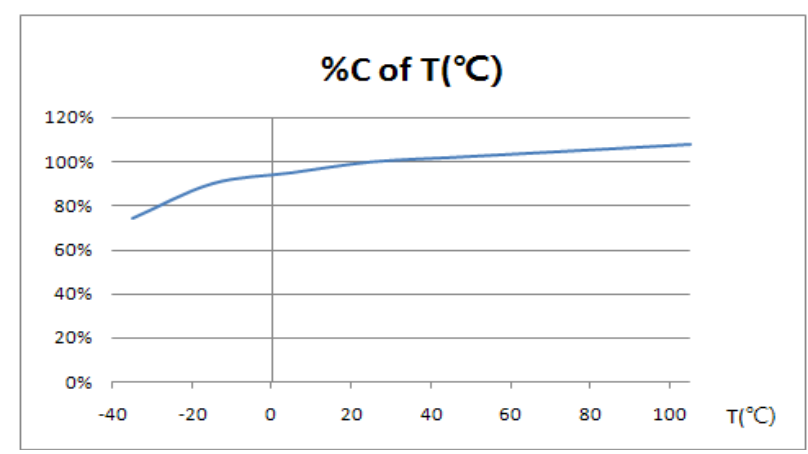

그림 13 온도 가변에 따른 기준 C값의 변화

Fig. 13 Capacitance results with the temperature variation.

또한 커패시터의 용량은 위의 그림 9 에서 그림 12 까지의 결과에서처럼 주파수에 의해 변하기도 하지만 온도에 의하 여 변하기도 한다. 그림 13 은 온도 가변에 따른 C값의 변화 를 나타낸 것이다. 이는 동작온도가 증가하면 커패시터의 커패시턴스는 증가함을 알 수 있다. 그리고 동작온도가 매 
우 낮을 경우 전해질의 활성도가 낮아져 커패시터 용량이 급격히 감소함을 알 수 있다. 또한 그림 14 는 다양한 주파 수에서의 온도가변에 따른 기준 $\mathrm{C}$ 값의 변화를 나타낸 것이 다. 주파수 조건에 상관없이 같은 패턴의 온도 가변에 따른 커패시턴스 $\mathrm{C}$ 값 특성이 있음을 확인 할 수 있다.

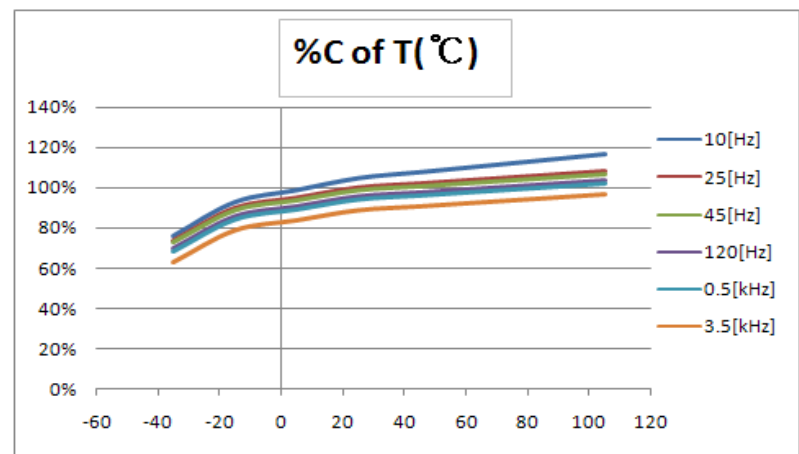

그림 14 다양한 주파수에서 온도 가변에 따른 C값의 변화

Fig. 14 Capacitance results with the temperature and frequency variation.

\section{6. 결 론}

본 논문에서는 전력변환 설비에 포함되어 있는 $\mathrm{DC}$ 연계 (link)부의 전해 커패시터 고장진단에 대하여, 외부변수를 고 려한 올바른 기준모델 입력을 설정하기 위하여 주파수 및 온도 변화에 따른 $\mathrm{ESR}$ 과 $\mathrm{C}$ 값의 변동 특성을 고찰하여 보았 다. 커패시터 파라미터를 전해질 및 온도에 영향을 받는 $R_{2}$ 와 $C_{2}$, 주파수에 영향을 받는 $R_{3}, C_{3}$ 로 구분하여 $\mathrm{ESR}$ 및 $\mathrm{C}$ 의 온도 특성뿐만 아니라 주파수의 변화에 따라 그 값의 특성을 다양한 측면에서 고찰하여 보았다.

그 결과 주파수 가변에 따라 $\mathrm{ESR}$ 은 저주파영역 $(f \leq 120[H z])$ 에서의 변화가 크며 특히 $25[\mathrm{~Hz}]$ 이하에서는 변 화가 매우 크다. 고주파 영역에서는 주파수 가변에 의한 $\mathrm{ESR}$ 의 변화는 매우 작아서 무시할 수 있다. 온도 가변에 따른 $\mathrm{ESR}$ 변화는 $25\left[{ }^{\circ} \mathrm{C}\right]$ 에서 초기치를 나타내고 온도가 증 가할수록 $\mathrm{ESR}$ 이 작아지는 것을 확인하였다. 특히, $15\left[{ }^{\circ} \mathrm{C}\right]$ 이 하에서는 $\mathrm{ESR}$ 의 변화폭이 크므로 세심한 주의가 필요하다 고 할 수 있다.

또한 주파수 가변에 의한 $\mathrm{C}$ 값은 고주파영역에서 변화가 크며, 저주파영역 $(f \leq 120[H z])$ 에서는 변화가 매우 미미하여 무시할 수 있다. 온도 가변에 따라 $\mathrm{C}$ 의 값은 점점 증가하지 만 $0\left[{ }^{\circ} \mathrm{C}\right]$ 이하에서는 크게 변하므로 별도의 해석이 필요하다 할 수 있으며, 커패시터마다 미세한 차이는 있지만 대부분 이러한 특성곡선의 패턴으로 추종되리라 예상된다. 따라서 주파수 및 온도 변화에 따른 $\mathrm{ESR}$ 과 $\mathrm{C}$ 의 기준모델 특성을 커패시터 고장 진단시스템에 반영한다면 보다 정확하고 신 뢰성 있는 시스템으로 구축되리라 예상하여 본다.

\section{감사의 글}

본 연구는 2012학년도 오산대학교 교내 학술연구 지원에 의하여 이루어진 연구로써 관계부처에 감사드 립니다.

\section{참 고 문 헌}

[1] United States Department of Defense, "US MIL -HDBK-217F Reliability Prediction of electronics Equipment," Version F, Notice 2, USA, 1995.

[2] M.L. Gasperi, "Life Prediction Modeling of Bus Capacitor in AC Variable-Frequency Drives", IEEE Trans. on Ind. Appl., vol., 41, no.6 ,pp.1430-1435, 2005, Nov./Dec.

[3] J.W. Kolar and S.D. Round,"Analytical calculation of the RMS current stress on the DC-link capacitor of voltage-PWM converter systems", IEE Proc.-Electr. Power Appl., Vol. 153, No. 4, pp.535-543, July 2006.

[4] P. Venet, F.Perisse, M.H. El-Hussein1 and G. Rojat, "Realization of a smart electrolytic capacitor circuit", IEEE of Industry Applications Magazine, No.1, pp. 16-20. 2002

[5] 손진근, "전력변환장치에서의 DC 출력 필터 커패시터 의 온라인 고장 검출기법", 전기학회 논문지, 제 $58 \mathrm{P}$ 권 제4호, pp. 483-489, 2009년 12월.

[6] 김동준, 손진근, 전희종, "Zigbee 무선통신을 이용한 UPS DC링크 커패시터의 고장 모니터링 시스템 개발", 전기학회 논문지, 제 $61 \mathrm{P}$ 권 제 1 호, pp. 41-46, 2012년 3 월.

[7] http://www.chemi-con.co.jp/e/index.html, "ALUMINUM ELECTROLYTIC CAPACITORS”, CAT. No. E10011.

저 자 소 개

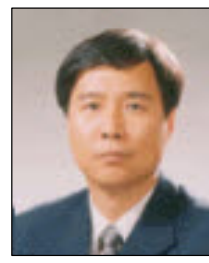

\section{박 종 찬 (朴 鍾 讚)}

1955년 12월 19일생. 숭실대학교 전기공 학과 졸업. 1988년 동 대학원 전기공학과 졸업(석사). 2002년 동 대학원 전기공학 과 졸업(박사). 1992년 현재 오산대학 전기시스템제어과 교수.

Tel : 031) 370 - 2672

E-mail : jcpark@osan.ac.kr

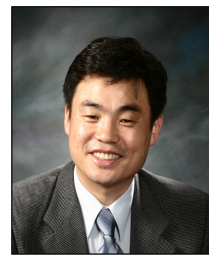

\section{손 진 근 (孫 珍 劤)}

1990년 숭실대학교 전기공학과 졸업. 1992/1997년 동 대학원 전기공학과 졸업 (석사/박사). 2002. 2 2003. 2 일본 가고 시마대학 전기공학부 Post-doc. 2009. 1 2010. 2 Michigan State University 방문교수. 1997년-현재, 가천대학교 전기 공학과 교수.

E-mail : shon@gachon.ac.kr 